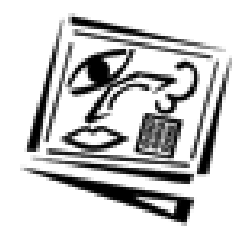

\author{
Australian Journal of \\ Educational Technology
}

1999, 15(1), 95-116

\title{
Exploiting the web for education: An anonymous asynchronous role simulation
}

\author{
Mark A. Freeman and John Capper \\ University of Technology, Sydney
}

\begin{abstract}
Whilst not all the possibilities of face to face teaching can be replicated on the World Wide Web, some can be undertaken which are impossible face to face. A role simulation, a hybrid of a role play and a simulation, is one such possibility. Students can engage asynchronously as well as synchronously. Participants in group exercises can be identified or anonymous. Moderation can be direct or with minimal interference. A role simulation, integrated into a flexible learning sequence in a graduate business subject, provides one example of exploiting the unique features of this emerging technology. Factors which would be potentially deleterious in a face to face context, such as those of gender, ethnicity and language proficiency, were ameliorated. A pilot test with a small cohort allowed the gathering of extensive data by means of interviews as well as survey methods. Positive learning outcomes and enthusiastic student and staff reactions suggest that other disciplines would also benefit from a similar innovative use of the web.
\end{abstract}

\section{Introduction}

This paper describes the learning and other outcomes of an anonymous asynchronous web based role simulation. In response to changes in the tertiary environment (eg. increasing competition, new technologies, busier student population), universities are increasingly pursuing flexible learning strategies. Technology enhanced teaching and learning systems, in particular the World Wide Web, have become common in many tertiary courses. Bates (1996) notes that because many technologies are so new, "no one has yet discovered all the interesting uses of the new technologies". Its potential for increasing immersion in learning tasks whilst reducing the impact of extraneous factors on student learning has only recently begun to be harnessed. This article looks at one particular learning task, an asynchronous anonymous online role simulation applied in a business course. Without the web it would be impossible to have such a learning task. This exploitation of the asynchronous and anonymous potential of the web is a response to Bates' call for new and interesting ways of using 
emerging technologies. This paper will be of interest to educators, irrespective of their disciplines, who are keen to increase the depth and enjoyment of their students' learning and are willing to explore the potential of technology to meet their aims.

\section{Literature review}

Whatever their field of study, academics want their students to learn the fundamentals of the discipline in a meaningful way (Ramsden, 1992). Quality learning of the principles of the discipline is more likely to result when students take a deep approach to learning the material (Marton and Säljö, 1997). Simply encouraging students to rote learn facts does little to change their understanding. The desired outcomes are more likely to result when academics help their students to understand the major concepts of the discipline and apply them to new situations (Marton and Booth, 1997).

Teaching is a skill which can be cultivated. Good grounding in the basics of one's own disciple alone does not make one a good teacher. Good teachers have to surrender any preconceptions which liken teaching to transmission. In its place they cultivate a desire to learn about themselves as teachers and a commitment to develop new methods and skills to assist students in their learning (Ramsden, 1992; Laurillard, 1993). Trigwell and Prosser (1996) show that teachers who view teaching as changing students' conceptions rather than merely information transmission are more likely to adopt a student centred approach. The latter is more likely to result in quality learning outcomes. To maintain vision and potency in teaching requires practitioners to try new methods to motivate student learning. This implies that they must also be willing to take risks. Technology offers new possibilities for innovation (Chickering and Ehrmann, 1997). The risk is reduced and the potential increased when one builds on the results of others. Ramsden (1992) notes that the introduction of a new learning task must be accompanied by adequate attention to assessment, since this highlights the importance of the task to students and motivates their activity.

\section{Emerging learning possibilities from new media}

Educational technology alone will not provide an adequate framework for innovation. It might be described as a missile looking for a target. Once the target is defined, the missile can be used for best results. This target is spotlighted by Ramsden (1992) who emphasises the benefits of a student centred approach, which maximises the benefits of multiple resources, 
whether or not these are related to technology. McQuillan (1994) shows that most benefits gained by introducing technology relate to changes in teachers' conceptions of, and consequential changes in instructional strategy, rather than the introduced technology itself. Freeman (1997) describes how strategically incorporating the internet can aid mass undergraduate teaching and learning.

Three possible benefits can result from effective integration of new information technologies (IT) into a strategic learning plan (Chong, 1997; Freeman, 1998). These are the enhancement of student learning; preparation of students for effective technology usage in their prospective workplace; and enabling staff to be more productive. Benefits do not flow, per se, from the technology itself. It is up to academics to shape the learning environment to best exploit the features of IT. There is a need for "appropriate frameworks to guide educational professionals in exploiting advanced information and communication technologies" Angehrn and Nabeth (1997, p.275).

New journals have appeared to carry the vast material written on the role of IT and education. There is both anecdotal and empirical evidence to suggest that use of IT can, if integrated appropriately into the learning plan, produce results at least as good as not using computers (Russell, 1997). Dixon (1996) cites data from the University of Phoenix which points to superior student outcomes with online education. Nevertheless, Adler and Milne (1998) note the reluctance of some educators to adopt learner centred approaches.

Change ought to be driven by educational objectives not technological desires. Integration of various methods with educational goals may mean the need to rethink the assumed strategic learning plan, not just the means of delivery. Part of the rethinking of strategy should entail the consideration of new learning tasks that become possible with new technologies. The role simulation is a suitable example.

Vincent and Shepherd (1998) pioneered this new application of a simulation by using teams of students researching and playing a significant role in Middle East politics. Initially teams pursued their player's agenda vis a vis other players via email. Some team members may be in another country, holding a strong and divergent view to that which they must help play. Without video conferencing technology, the students from different countries could not play out the 'summit talks'. 


\section{Simulations and role plays}

Simulations are often used in business education for training in management and decision making (Tonks and Armitage, 1997). Recent moves have seen simulations made available on the web (Cox and Saunders, 1996; Lawrence, 1997). Role plays are a particular subset of simulations, usually differentiated by length and complexity (Gredler, 1992). Role plays have been widely used in education at all levels (Chesler and Fox, 1966). They find particular application in relational contexts, typically in such areas as counselling and negotiation training (Bollens and Marshall, 1973). Simulations have come to be seen as a particular, stand alone, learning tool when used on computers. We have termed our learning event a "role simulation" as it is something of a hybrid, involving the personal aspects of a role play with the computer based dimensions of a simulation. The aim of the role simulation is akin to that of a role play: to experience the factors at work in a real situation but without the potentially devastating consequences. With a role simulation, as with a role play, there is no one right answer, but a range of means of engagement in working towards a resolution.

Role plays are under used in other areas of education, due to the perception of the role play as a "high risk" strategy (Thompson, 1978). While a role play is risky if players do not respect each other, it also carries great potential for quality learning. Bloom (1956) and Krathwohl, Bloom and Masia (1964) argue that an effective role play can engage both the affective and cognitive domains. Its effects spill over into the "active" (Sliepsevich, 1967) or "volitional" (Westerhoff, 1976; Fowler, 1987) domain. One attribute of role plays, that they can be fun (Ladousse, 1987), may be a factor in both student learning and teacher anxiety.

Playing a role, whether in a role play or a simulation, is not mere acting but the adoption of a behavioural repertoire or social position (Biddle and Thomas, 1966). In a role play that adoption is "short and episodic" (Jones, 1988), and at the control of the participant, with guidance from experienced fellow "players" and teachers. Simulations, in their extended nature, can be used to draw out subtler nuances than stand alone role plays normally allow (Ladousse, 1987).

A role play "sharpens skills of expression, observation and analysis [and] provides exposure to the complexity of real problems" Bollens and Marshall (1973, p.88). Students exposed through role plays to situations 
likely to be encountered in their professional lives are more likely to make the right decisions in similar cases in future (van Ments, 1989). A role play may also "lead to new assessments of...different positions" and "increase empathy for real participants in real life situations" (Bollens and Marshall, 1973, p.88; 90). Using students from several countries including the Middle East, Vincent and Shepherd (1998) observe the improved empathy students appear to have gained by having to pursue political agenda strongly opposed to their own. Thompson (1978, p.10) specifically notes this increased empathy as happening in the context of people adopting the role of the opposite gender. Role plays offer benefits for shy students (Ladousse, 1987).

Teachers planning to use role play and simulation methods need to be clear on the goal(s) to be achieved and the limitations inherent in the learning context, such as language, student preconceptions, space and time. Three essential steps can be identified in an effective role play (Chesler and Fox, 1966):

- Preparation and instruction. Teacher and roles must be prepared and students must be adequately instructed in the acting out of their roles. Potential problems must be anticipated (Turner, 1992, p. 37);

- Action and discussion. The role play needs time and space to happen adequately. Participants need time to dissociate from their roles and begin the reflective discussion which follows. This should connect them to the problem which was to be addressed (van Ments, 1989).

- Evaluation. Students should be encouraged to evaluate the impact of the role play on their learning and teachers need to evaluate the effect on student learning. Feedback should inform future usage (Ramsden, 1992).

One of the drawbacks of a role play is the dimension of performance, which raises concern in participants and educators. Concerns raised in face to face role plays and simulations include fear, anxiety and guilt. These feelings can be found in facilitators as well as students, so it is important to remind all participants of the importance of acting responsibility, especially where the feelings and opinions of others are involved (van Ments, 1989). There are various techniques to reduce these resistances (Jones, 1988), provided that the objective of the simulation is clearly understood, and appropriate moderation and supervision are provided. 
The web offers several possibilities for improvement over face to face role plays. First, if structured properly, participants can remain anonymous. This goes further to reducing the resistances discussed above. Anonymity can also overcome some of the concerns raised above with face to face performance. Second, asynchronicity allows students more time to reflect on the appropriate response for their role.

The benefits of anonymity are noted by Connolly, Jessup and Valacich (1990) who found that in a computer mediated group, more and better ideas were generated where the group members were anonymous and had a critical member who challenged ideas. This may be a benefit not only of anonymity per se, but of the reduction of some interpersonal barriers. Olaniran, Savage and Sorenson (1996) found that despite some student resistance to their initial experience, computer based groups produced significantly more ideas than face to face groups.

Anonymity, however can be a hazard to the development of academic community (Pence 1996, p.93). Measures to reduce anonymous harassment for example can be implemented. In the context of an adult learning community, this hazard is minimised by shared objectives, clear expectations of circumspection and mutual respect. In some cases it may also be possible to trace harassing message senders through IP addresses. A warning to this effect may be an incentive to minimise this hazard.

Asynchronicity allows students to think through their responses before committing themselves publicly. This has particular benefits for students who are socially or linguistically disadvantaged, shy or uncertain (McComb, 1994). Participants can seek help from various resources outside of the classroom in preparing their contributions (Graziadei, 1998).

\section{Context}

Students in a graduate business program studying the regulation of securities markets were presented with two conflicting paradigms - those of finance and law. Efficiency solutions are the primary concern of the former, whilst equity undergirds the approach of the latter. The tension was heightened by the participation of an academic from each field in each of the three face to face weekend schools. The contrasting views of securities markets regulation were pursued in the intervening monthly periods between face to face classes with the aid of an integrated, off the shelf, web based learning program used for private and public interaction 
as well as coursework. Although TopClass is a secure, password protected proprietary program, students have repeatedly commented on its ease of use. In 1998 a web based teaching forum was used for a series of team debates and for the first time for an anonymous asynchronous role simulation.

A flexible assessment package attempted to integrate the course learning objectives and learning resources. These included team based class presentations (some as face to face role plays), web debates and quizzes. The other 50\% comprised individual tasks: the role simulation, pre- and post-role simulation concept maps and a final examination case study. Marks which would have been allocated to the optional role simulation were allocate to the final exam for those who chose not to participate. Students were specifically encouraged to adopt different perspectives from their own through three learning tasks, namely the web debates, the face to face presentations and the anonymous asynchronous online role simulation.

Of the twenty four postgraduate students studying Securities Markets Regulation (SMR) at the University of Technology, Sydney, all but three chose to be involved in the online role simulation. $75 \%$ were studying part time and $58 \%$ were male. Since such a high proportion of students had a non English speaking background (71\%), the benefit of allowing time through asynchronicity for research about Australian securities markets was expected. In addition, it was expected that such students would benefit from time for reflection and formulation of argument in an asynchronous role simulation. By keeping the identity of the student playing each role anonymous, issues of gender and cultural expectations evident in an embodied encounter were minimised, heightening student engagement with the learning task itself. $81 \%$ of students had access to computing facilities external to the university, with $73 \%$ of these connected to the web.

The web role simulation was conducted after the final weekend school. The need for a thorough understanding of the subject to create an effective simulation dictated the positioning of the role simulation near the end of the course. Precise instructions were handed out and discussed just before closure of the face to face session. As they left the session, students were given the role of a major figure involved in the process of regulating Australian securities markets with strict instructions (and an explanation of why) not to disclose their role identity to other members of the class. Given the high percentage of part time students in the class and the fact 
that few knew each other before the course, we expected anonymity to be retained. That there were surprises for participants as to who was placing which role at the final "coming out" indicated that this had been achieved.

Students had a week to research the role they were to play and then posted this to the website. They were asked specifically to indicate their perceptions of the concerns, ambitions and strategies of their role. This formed the basis from which they were to participate in the role simulation. They then responded in role (eg. Australian Treasurer Peter Costello) over ten days to a series of events (eg. currency crises), announced through "press releases" to the group. Press releases were developed jointly by the two academics to ensure realistic and relevant dilemmas allowing all roles some chance of participating. That the role simulation portrayed possible real world events is seen in that some have since happened. Players could respond in role through the "public" forum Discussions, or could approach each other privately in role via Send Messages within TopClass[1]. Students were assessed on their private and public postings and their role profile[2]. Roles were kept anonymous until a "coming out" at the final examination case study. To adequately reward participation in the role simulation, $15 \%$ was allocated to the role simulation (5\% each to the role profile, quantity and quality of input) and $15 \%$ to the concept maps (5\% pre and $10 \%$ post-role simulation)[3]

\section{Evaluation}

Alexander and McKenzie (1998) note the need for a holistic approach to evaluation, which takes into account the concerns of and costs and benefits to a range of stakeholders. It is also important to utilise a variety of methods to triangulate outcomes and avoid the distortions evident in any one form of evaluation used in isolation (McKenzie, 1998). For example, details on student learning need to be sought as well as student reactions. Available funding allowed the role simulation to be thoroughly evaluated. Data gathering methods used included student and staff surveys, arranging interviews with all class members (whether role simulation participants or not), analysis of the threaded discussions and private email for each role, a reflective diary kept by the education researcher involved, and attention to unsolicited student comments.

The survey instrument used included questions of demographics, access to and familiarity with computers, access to and experienced usefulness of 
the learning resources available in the course, and a series of questions to identify students' preferred approach to learning, based on Biggs' (1987) study process questions. Students were also asked five open ended questions as to what was most helpful to them in the course and asking for suggestions for improvements.

The individual interviews were informally conducted, normally with students on campus or in their workplace. The prepared questions addressed issues of content and process and were used more as a guide than a program. They sought to elicit feedback on the whole course as a learning experience including the change in students' understanding of securities markets regulation. Nevertheless, the interviews were particularly focused on the role simulation experience and what students learned through it. Each interview covered the student's approach to the role simulation, any difficulties encountered, the student's perception of what was learned, the effect of anonymity and the integration of the role simulation with other learning tasks. Students were asked specifically whether they would advise students in subsequent offerings of the course to attempt the role simulation, and what advice they would offer to the course coordinators for its improvement. Each interview lasted between 35 and 60 minutes and each was taped and transcribed for later analysis. One interview which could not be undertaken in person was undertaken by telephone.

The surveys and interviews, along with student assessment results, comprise the major source for the results which follow. These are discussed in regard to reaction, outcomes achieved, skills transfer and organisational impact (Kirkpatrick, 1994).

The effects on other stakeholders, notably the staff members involved, is also reported. This is based on interviews and informal discussions between the academic coordinators and an independent educational researcher. A diary was used to note issues arising from this role simulation and ideas for improving future applications.

\section{Results}

Results are discussed under two main headings: student effects and other stakeholder effects. The student effects are discussed in four sections. First, we describe student reactions to the role simulation, illustrated by some rich feedback gained from the interviews. Second we compare student performance in the subject with previous years and note their comments on learning outcomes. Third, we note skills developed by students. Fourth, 
issues gleaned from the interviews as to the impact on other organisations are noted. To contextualise these four sections, we begin with some comments on the patterns of student involvement with the role simulation.

\section{Student effects}

Whilst it had been expected that students would log in to the role simulation regularly, the number of logins was surprising, as Figure 1 shows. Many students logged in not just once or twice per day, but a number of times in an hour, to read, respond and respond again. There were short periods of almost synchronous debate when a large number of students were all logged on together. The busiest times of day were mid and late afternoon with 30 to 50 logins per hour. The number was between 10 and 20 per hour from 10pm until 1am. Half of all logins were outside of $9 \mathrm{am}$ - 5pm business hours. This is significant indication of student commitment, with $75 \%$ of the class being part time.

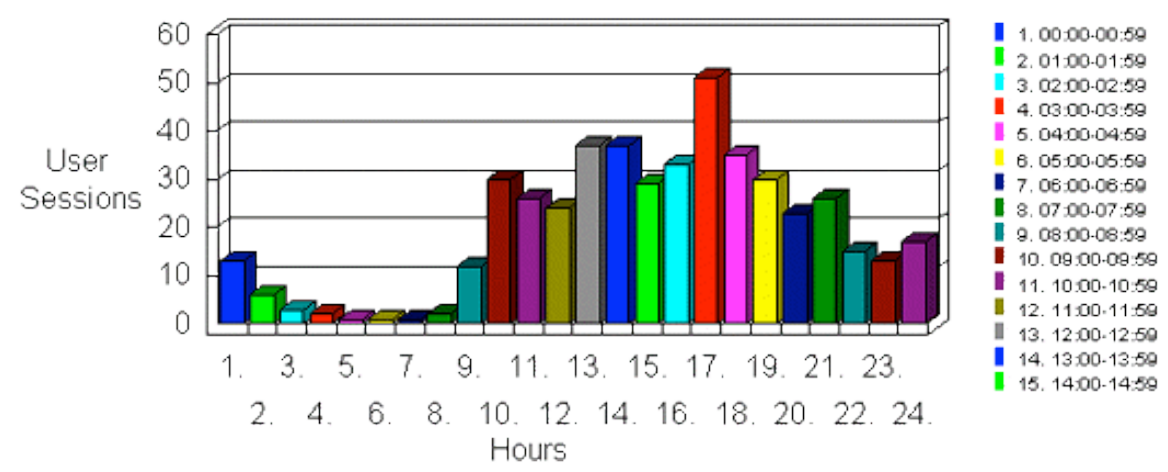

Figure 1: Activity level by hour of the day

The number of user sessions, averaged on a daily basis, is shown by Figure 2. The rate of both public postings (from one role character, visible to all) and private postings (from one character to another alone) increased significantly through the period - a function of both the pressure of deadlines and the growing interest in the many nuances of debate which developed. The average user session increased from 15 minutes at the beginning of the role simulation to nearly 30 minutes by its conclusion. 


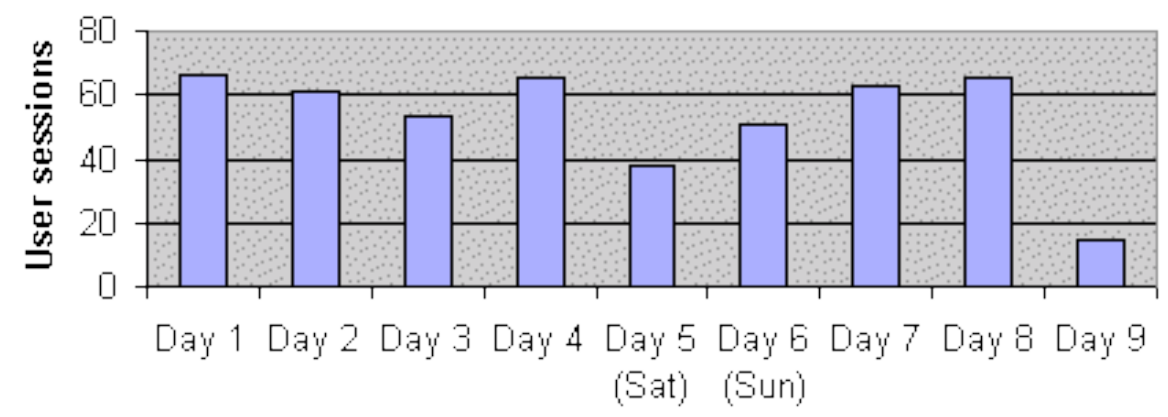

Figure 2: User sessions through the role simulation

Note: On the final day the debate was only open until midday.

The average time spent using the medium for different web based learning tasks is shown in Figure 3. This suggests that students were more deeply immersed in the web based role simulation than is usual for other tasks.

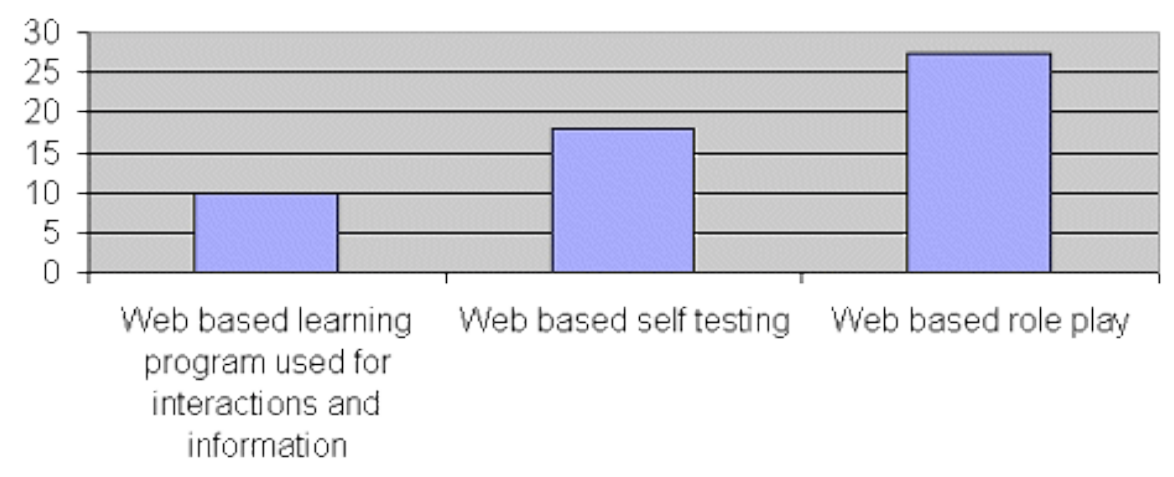

Figure 3: Average session time for different web based learning tasks

\section{Reactions}

Students' support for the role simulation as a learning task was indicated in the end of course pilot survey. Of 20 learning resources or learning tasks that students were asked to rate in the survey, the role simulation and preparation of the role profile were rated as the most useful (based on the sum of the "very useful" and "extremely useful" responses). The reaction results from the survey are summarised in Table 1. 
Table 1: Student rating of learning resources or learning tasks $(\mathrm{n}=21)$

\begin{tabular}{|c|c|c|c|c|c|}
\hline & Useless & $\begin{array}{l}\text { Not very } \\
\text { useful }\end{array}$ & Useful & $\begin{array}{c}\text { Very } \\
\text { useful }\end{array}$ & $\begin{array}{l}\text { Extremely } \\
\text { useful }\end{array}$ \\
\hline Announcements on TopClass & $5 \%$ & $5 \%$ & $48 \%$ & $29 \%$ & $14 \%$ \\
\hline $\begin{array}{l}\text { Lecturer responses in SMR } \\
\text { discussions on TopClass }\end{array}$ & $0 \%$ & $10 \%$ & $62 \%$ & $14 \%$ & $14 \%$ \\
\hline $\begin{array}{l}\text { Other students' questions and } \\
\text { answers in SMR discussions on } \\
\text { TopClass }\end{array}$ & $5 \%$ & $5 \%$ & $76 \%$ & $10 \%$ & $5 \%$ \\
\hline $\begin{array}{l}\text { Private send and receive TopClass } \\
\text { messages to discuss the case study } \\
\text { with my team }\end{array}$ & $5 \%$ & $14 \%$ & $52 \%$ & $19 \%$ & $10 \%$ \\
\hline $\begin{array}{l}\text { Use of TopClass for the online } \\
\text { debate }(\mathrm{n}=20)\end{array}$ & $0 \%$ & $10 \%$ & $50 \%$ & $30 \%$ & $10 \%$ \\
\hline $\begin{array}{l}\text { Links and references in the } \\
\text { coursework folder on TopClass }\end{array}$ & $0 \%$ & $24 \%$ & $29 \%$ & $29 \%$ & $19 \%$ \\
\hline Tips in TopClass & $0 \%$ & $14 \%$ & $48 \%$ & $24 \%$ & $14 \%$ \\
\hline $\begin{array}{l}\text { PowerPoint slides available in } \\
\text { TopClass } \\
\end{array}$ & $5 \%$ & $14 \%$ & $43 \%$ & $19 \%$ & $14 \%$ \\
\hline $\begin{array}{l}\text { References for each topic available } \\
\text { on TopClass }\end{array}$ & $10 \%$ & $14 \%$ & $38 \%$ & $19 \%$ & $19 \%$ \\
\hline $\begin{array}{l}\text { Preparation of the draft concept } \\
\text { map }\end{array}$ & $14 \%$ & $10 \%$ & $33 \%$ & $33 \%$ & $10 \%$ \\
\hline $\begin{array}{l}\text { Preparation of the final concept } \\
\text { map }\end{array}$ & $10 \%$ & $10 \%$ & $48 \%$ & $24 \%$ & $10 \%$ \\
\hline $\begin{array}{l}\text { Preparation of the role profile (if not } \\
\text { involved, leave blank) }(n=18)\end{array}$ & $6 \%$ & $6 \%$ & $33 \%$ & $44 \%$ & $11 \%$ \\
\hline $\begin{array}{l}\text { Participation in the role simulation } \\
\text { (if not involved, leave blank) }(n=16)\end{array}$ & $6 \%$ & $13 \%$ & $25 \%$ & $38 \%$ & $19 \%$ \\
\hline $\begin{array}{l}\text { Group work with other students } \\
(\mathrm{n}=18)\end{array}$ & $0 \%$ & $6 \%$ & $67 \%$ & $22 \%$ & $6 \%$ \\
\hline $\begin{array}{l}\text { Browsing sites about securities } \\
\text { markets or regulation on the } \\
\text { internet }(n=19)\end{array}$ & $11 \%$ & $11 \%$ & $37 \%$ & $37 \%$ & $5 \%$ \\
\hline $\begin{array}{l}\text { Printed information about the } \\
\text { securities market (eg newspapers) } \\
(\mathrm{n}=20)\end{array}$ & $0 \%$ & $10 \%$ & $60 \%$ & $20 \%$ & $10 \%$ \\
\hline Doing the team presentation $(\mathrm{n}=20)$ & $0 \%$ & $5 \%$ & $55 \%$ & $35 \%$ & $5 \%$ \\
\hline $\begin{array}{l}\text { Individual discussions with other } \\
\text { students }(\mathrm{n}=20)\end{array}$ & $0 \%$ & $15 \%$ & $55 \%$ & $25 \%$ & $5 \%$ \\
\hline $\begin{array}{l}\text { Individual discussion with the } \\
\text { lecturers (on the phone or in } \\
\text { person) }(n=20)\end{array}$ & $5 \%$ & $5 \%$ & $50 \%$ & $25 \%$ & $15 \%$ \\
\hline $\begin{array}{l}\text { Preparing for the final application } \\
\text { case study }(n=19)\end{array}$ & $0 \%$ & $21 \%$ & $47 \%$ & $26 \%$ & $5 \%$ \\
\hline
\end{tabular}

Note: Rounding may mean some rows do not add to exactly $100 \%$ 
The freehand responses also pointed to the value of web resources generally and the role simulation particularly. One in three respondents mentioned web resources as most helping them learn securities markets regulation. One student noted the "immediacy and flexibility of the internet" as most helpful in learning. One of a number who highlighted the role simulation said that it "was fun and very helpful in our preparation" (for the final assessment case study). One student called for more explanation of the role simulation. This stood alongside other requests for clarification, which proved to be common for all assessment tasks. This was not surprising, given the innovative nature of the tasks and their contrast to students' expectations of assessment based on 'one essay and one final exam'.

The richest statements of reaction are evident from the interviews. The role simulation aroused considerable interest amongst the course participants as well as their families and colleagues. Two non-participating students, though not having access to computers, had a participating colleague fax them the postings so that they could follow the role simulation. All nonparticipants regretted their non-involvement, and would have participated had they undertaken the course again. All students but one (an overseas student with neither own computer nor web access) said they would recommend participation to future students.

The anticipated comment regarding student enjoyment of the learning task was in evidence. One Australian male commented: "It was a lot of fun going in there and seeing responses to something you had put on there. I found it good."

That the anonymity helped with student accessibility was borne out in the interviews. This was particularly so for the students not native to Australia and from a non-English speaking background (NESB). As an Asian NESB male observed: "I found it quite fun to act out the roles because no one knows who you are and so you get to say what you want." An Asian NESB female echoed this: "It is easier to criticise other players without having to worry if they are your friends."

Similarly, anonymity was perceived to contribute to learning: "It was a good thing for me [to be] anonymous... if I use my name everybody knows me and my thinking. [Anonymity allowed me] to learn by trying to do what a [central banker] normally does." (Overseas NESB male) The immersion in the learning task was exemplified even more starkly by another overseas male NESB participant who said: "The anonymity didn't matter to me, because in my mind I was (role name)". 
Whilst role identity was concealed from the group by all participants, one noted of others that "The way they were speaking gave them away." However he went on to add that "It would have had factions forming and it would not have worked as well...personal attacks and private assassinations may have occurred if it wasn't anonymous." Even though some participants thought they had guessed who was playing certain roles, "final revelation of the players behind the roles held some surprises, indicating that some stereotypes had been challenged." (Academic coordinator).

The depth of commitment to the learning process was indicated by an overseas NESB male who said: "It [the role simulation] is quite fun. The problem is I have to work and... my answering the role play is usually at $4.00 \mathrm{am}$. I borrowed a friend's Internet [access] and... used it for a few days."

\section{Learning outcomes}

Overall learning outcomes were achieved at least as effectively with the inclusion of the role simulation as they had been in previous years. A comparison of students' performance with the previous year yielded no significant difference despite the inclusion of the role simulation in 1998. This was evident also in student performance in the final exam case study. Neither was there a significant improvement in the post-role simulation concepts maps. Freehand responses showed considerable learning, with students commenting that they better understood the dynamics of the securities market.

Indicators of quality learning were found in the interviews. Students came to understand the complex pressures at work on regulators and market participants. They had to deal with pressures of time and "public" reaction as well as learning to represent complex organisations in unfamiliar scenarios. They achieved a deeper understanding of their own views (as student and in role) as well as those of other stakeholders. Students also came to appreciate the limitations of the two main paradigms in practical contexts. The role simulation formed an enjoyable means of revising for the final examination case study. The following excerpts from post course interviews indicates the links that students made between the classroom and practice as well as the commitment students made to participation in the role simulation: 
"Before [the role simulation] I focused on the finance side...how the markets work...but I didn't really see the regulation side. Now I can see the regulators, what they are going through, and the way it links the whole course (Master of Business) together." (Overseas NESB male).

One non-participant who nonetheless observed the role simulation commented that it "brought it all together, in a novel way", noting it was "very different to my normal way of learning, it wasn't memorising".

One overseas born NESB female commented: "I have been here 5 years and never watched the [federal] budget with so much interest...I just sat down and I knew the budget just like that"

\section{Skills}

Student responses in interviews indicated that they had developed considerable skills in use of internet technology and resources as well as in their understanding of the particular subject matter of the course. In freehand survey responses, $30 \%$ of respondents noted their satisfaction at having learned internet skills. One student commented of learning through the "immediacy and flexibility of the internet". In interviews a similar pattern was observed, with one overseas student saying that he learned "a whole lot just finding the (Australian Treasury) site".

An Australian male, not previously a user of the internet said: "[The role simulation] really increased my knowledge of the internet and I feel very confident about that." Another said that he had changed his approach to resources, opening up his horizons to electronic means and growing in familiarity with their use and power. "[The role simulation] has made me aware that if ever I need some information on something...that's one place I can look...yet I didn't realise that all this sort of information would be already on the internet." (Australian male).

Skills of analysis and negotiation were also in evidence. In the role simulation, one participant was placed in a position where his/her role had to take another role to task 'publicly' for misrepresentation of various issues and misuse of the media. This exemplified the clarity of skills developed. Similar skill was found in the analysis of the 'private' mailings between the different players. 


\section{Organisational impact}

A number of students reported that the role simulation had raised interest and discussion in their households and workplaces. The novelty of the learning task was described by one student as of interest to others who would not otherwise have been interested in her studies and thus a means to talk with them about what she was learning. One banker spoke of the interest of his colleagues in his involvement in the learning event and similar interest in how he was playing the role he was given. No direct evidence of actual change in these institutions, whether family or workplace, can be given.

One overseas student said that she hadn't realised how similar the tensions within Australia's regulatory system was to those of her European home country. The potential long term impact was underscored by another overseas participant, who said "I was very fortunate to study Australia's regulation - it may contribute to my own country's regulation in the future." This same student commented "I now know how it feels to be a central banker".

Another student noted that the experience of having done the role simulation would be something worth noting when applying for a job, as it would show the breadth of skills accumulated during degree studies. Not only had this person learnt about securities markets regulation, they had also perceived their learning as adding value to a prospective employer's organisation.

\section{Staff and other stakeholders}

The main burden from integrating the role simulation was the heavy time commitment required by staff. Considerable time was spent undertaking research on the method, designing tight instructions, formulating appropriate current press releases and monitoring the role simulation responses. The only other burden was the extra stress from the risk of failure of either the technology or the role simulation itself. Fortunately, neither eventuated during the course of the role simulation. As it became evident that students were immersing themselves in the task, having fun and learning an alternative perspective and gaining a better understanding of the process of securities markets regulation, the stress was substantially ameliorated. In fact, the experience was highly satisfying to those involved, as the role simulation proved to be a powerful tool for displaying and allowing students to experience the clash of paradigms in 
what can otherwise be a dry descriptive exercise. The heavy investment in design and evaluation has already yielded benefits, and will continue to do so in the future both for existing staff and their colleagues[4]. As well, future student cohorts will benefit not only from a refined role simulation as a learning task, but will also have a benchmark set for them in the present role simulation results. The best items of the 1998 role simulation will be used to demonstrate what is possible to future enrolling students.

Previous use of web based teaching resources and anecdotal information provide horror stories of equipment failure and software deficiencies which have spoiled innovative tasks. This was not experienced in this trial, due to a growing pool of experience in educational design and technology support. That the University has a central strategy for supporting flexible learning which is well resourced allowed a climate in which the role simulation could proceed with a high level of confidence. Of course, there can be no guarantees of IT stability, so some stress will always exist. Advice from a range of internal and external educational experts, including discussion with staff and students in the Middle East politics simulation, assisted the development of the role simulation. This necessitated a rethink of the whole course, particularly assessment tasks. For example, the concept maps proved a vital inclusion as a result of this revision. Staff involved strengthened existing skills as well as adding new ones (eg role simulation, concept maps and internet skills). The hard work of writing this new learning task has been rewarded through the quality of student learning, the development of staff skills, the overall improvement of the course and the availability of a tested resource for future years.

Future plans will include a number of improvements based on the research from this trial. The first of these will be more provision for student self evaluation of the role simulation as a learning experience. The short "coming out" will be extended to allow students to reflect (in role and as themselves) on what they have learned through the role simulation. This evaluation may include extending self and peer assessment to this reflection and on their participation within the role simulation itself. Building on the success of this trial, moves are in hand to expand the possibilities available to students by the addition of Internet Relay Chat (IRC) to the role simulation next year. The concept maps will be retained and practice exercises will be used earlier in the course. They have proved themselves to be useful in helping students to grasp complex conceptual inter-relationships. 
The role simulation, undertaken in this anonymous asynchronous mode, appears to work best where there is a natural conflict between concepts and where participants bring strong pre-conceptions or misconceptions to the class. Topic areas which are complex and ambiguous are especially suited to this form of role simulation. They offer the possibility of an intense and immersing exercise with the likelihood of quality learning outcomes.

Colleagues in other faculties and other disciplines, including science, engineering, law, education and theology, have indicated their interest in utilising this innovative learning task both on their own and in collaborative projects. Plans are also in train to develop joint ventures with other institutions. The project has received ongoing encouragement and interest from the University's Flexible Learning Action Group, to whose members ongoing research results have been presented, as well as to special interest learning groups at conferences and other universities. It received the award for best Internet project at ASCILITE (Australasian Society for Computers in Learning in Tertiary Education) in December 1998.

\section{Conclusion}

The outcomes of an anonymous asynchronous web based role simulation with post graduate business students have been described. Without the web, such a learning task is simply not possible. Consistent with Chong's (1997) expected benefits of integrating IT into the strategic learning plan, the interviews, surveys and discussion analysis indicate that the role simulation enhanced student learning and helped prepare students for effective technology usage in the workplace. The anonymity appeared to allow students to challenge their own stereotypic views of gender and race as well as their views about the content of securities markets regulation.

Consistent with McQuillan's (1994) observation, staff benefited by having to rethink the whole learning experience to accommodate the role simulation. This innovative learning task proved an effective payoff for the investment of time and the risk taken. It will be useable with less effort in future years to help students to achieve quality learning outcomes in this course and in others.

The concept of an anonymous asynchronous role simulation is proving to be of interest to academics in the sciences and humanities, and should find application amongst trainers in many disciplines. Its use in a crossdisciplinary context shows something of its diversity. It appears to show 
greatest potential when the subject matter has an inherent conflict or ambiguity. The conflicting agendas of efficiency (the Finance perspective) and equity (the Law perspective) in securities markets regulation demonstrated this. The possibility of connecting the learning task with contemporary community issues (eg. neighbourhood conciliation and public policy debate) and events provides great opportunities for creative teachers at all levels to contextualise their material. The possibilities of the web allow these benefits to be shared without regard for traditional barriers of culture and distance. The challenge which lies ahead is for educational designers to maintain positive standards when anonymity is used so that the integrity of participants is respected. These possibilities and their application need to be the subject of future research.

\section{Notes}

1. Demonstrations of aspects of the role simulation can be found at http:/ / www.bus.uts.edu.au/fin\&econ/staff/markf/ roleplay/rp_outline.html\#demos

2. Students were warned not to use their role login account for any personal messaging because private email as a norm cannot be accessed by staff for privacy reasons.

3. The three students who chose not to participate had $25 \%$ more riding on the final case study, written under exam conditions, otherwise worth $45 \%$.

4. Interested colleagues can explore the dynamics of the role simulation further at the site:

http:/ / www.bus.uts.edu.au/fin\&econ/staff/markf/roleplay/rp_outline.html\#demos

\section{Acknowledgments}

The authors wish to acknowledge the contributions of Andrew Vincent, Shirley Alexander, Jo McKenzie, James Sawers, Michael Adams, Phillipa Morris and Robert Rintoul. All errors remain the authors'. Funds for the development, evaluation and research arose from a 1997 Australian Award for University Teaching from the national government. This is gratefully acknowledged. 


\section{References}

Adler R.W., and Milne M.J. (1998). Identifying and overcoming obstacles to learner-centred approaches in tertiary accounting education: A Field Study of Accounting Educators' Perceptions. Paper presented at AAANZ Annual Conference, Adelaide.

Alexander, S. and McKenzie, J., with Geissinger, H. (1998). Evaluating IT projects for university learning: The CAUT experience. EIP study, Australian Government Publishing Service.

Angehrn, A., and Nabeth, T. (1997). Leveraging emerging technologies in management education: research and experiences. European Management Journal, 15, 275-85.

Bates, A.W. (1996). The impact of technological change on open and distant learning. Keynote at Open Learning Conference: Your future depends on it. Brisbane.

Biddle, B.J. and Thomas, E.J. (1966). Role Theory: Concepts and research. New York, John Wiley \& Sons.

Biggs, J.B., (1987). The Study Process Question (SPQ) User's Manual. Hawthorn, Vic, Australian Council for Education Research.

Bloom, B.S. (Ed), Engelhart, M.D., Furst, E.J., Hill, W.H., and Krathwohl, D.R. (1956). Taxonomy of Educational Objectives: The classification of educational goals. Handbook 1 - Cognitive Domain. London, Longmans.

Bollens, J.C. and Marshall, D.R. (1973). A guide to participation: Fieldwork, roleplaying cases and other forms. Englewood Cliffs, NJ, Prentice-Hall.

Chesler, M. and Fox, R. (1966). Role playing Methods in the Classroom. Chicago, Science Research Associates.

Chickering, A.W. and Ehrmann, S.C. (1997). Implementing the seven principles: Technology as lever. http:/ / www.aahe.org/technology/ehrmann.htm

Chong, V.K. (1997). Student Performance and Computer Usage: A Synthesis of Two Different Perspectives. Accounting Research Journal, 10(1), 90-97.

Connolly, T., Jessup, L.M. and Valacich, J.S. (1990). Effects of anonymity and evaluative tone on idea generation in computer-mediated groups. Management Science, 36(6), 689-703.

Cox, B. and Saunders, P. (1996). Designing a Cyber-based Business Simulation. Journal of Computing in Higher Education, 8(1), 29-47.

Dixon, P. (1996). Virtual College. Princeton, NJ, Petersons.

Fowler, J.W. (1987). Faith Development and Pastoral Care. Philadelphia, Fortress Press. 
Freeman, M.A. (1997). Flexibility in access, interaction and assessment: The case for web-based teaching programs. Australian Journal of Educational Technology, 13(1), 23-39. http:/ / www.ascilite.org.au/ajet/ajet13 / freeman.html

Freeman, M.A. (1998). Educational innovation: Hype, Heresies and Hopes. Paper presented at AAANZ Annual Conference, Adelaide.

Graziadei, W.D. (1998). Building Asynchronous and Synchronous Teaching-Learning Environments: Exploring a Course/Classroom Management System Solution. New York, SUNY. http: / / exon.itec.suny.edu/ west/aslpaper.html

Gredler, M. (1992). Designing and Evaluating Games and Simulations: A Process Approach. London, Kogan Page.

Jones, K. (1988). Interactive Learning Events: A guide for facilitators. London, Kogan Page.

Kirkpatrick, D. (1994). Evaluating Training Programs: The four levels. San Francisco, Berrett-Koehler.

Krathwohl, D.R., Bloom, B.S. and Masia, B.B. (1964). Taxonomy of Educational Objectives: The classification of educational goals. Handbook 2 - Affective Domain. London, Longmans.

Krathwohl, D.R. (1994). Reflections on the taxonomy: Its past, present, and future. In L.W. Anderson, L.A. Sosniak, and K.J. Rehage (Eds), Bloom's Taxonomy: A forty-year retrospective. Ninety-third Yearbook of the National Society for the Study of Education, Chicago, Illinois, The University of Chicago Press, 181-202.

Ladousse, G.P. (1987). Role Play. Oxford, Oxford University Press.

Laurillard, D. (1993). Rethinking University Teaching: A Framework for Effective Use of Educational Technology. London, Routledge.

Lawrence, P.J. (1997). Business simulations: Dynamic, computer based case studies for management development. International Federation for Information Processing Conference Proceedings. Melbourne, July 1996. London, Chapman \& Hall, 128-36.

Marton, F. and Booth, S. (1997). Learning and Awareness. Mahwah, NJ, Lawrence Erlbaum.

Marton, R. and Säljö, R. (1997). Approaches to Learning. In F. Marton, D. Hounsell and N.J. Entwistle (eds), Approaches to Learning. 2nd ed, Edinburgh, Scottish Academic Press, 39-58.

McComb, M. (1994). Benefits of Computer-Mediated Communication in College Courses. Communication Education, 43, 159-170.

McKenzie, J. (1998). Evaluating and documenting flexible learning projects. Working paper, University of Technology, Sydney.

McQuillan, P. (1994). Computers and pedagogy: The invisible presence. Journal of Curriculum Studies, 26(6), 631-653. 
Olaniran, B.A., Savage, G.T. and Sorenson, R.L. (1996). Experimental and Experiential Approaches to Teaching Face-to-Face and Computer-Mediated Group Discussion. Communication Education, 45(3), 244-59.

Pence, H.E. (1996). What is the Role of Lecture in High-Tech Education? Journal of Educational Technology Systems, 25(2), 91-96.

Ramsden, P. (1992). Learning to teach in higher education. London, Routledge.

Russell, T.L. (1997). The 'No Significant Difference' Phenomenon. http: / tenb.nbcc.nb.ca/ phenom/

Sliepsevich, E.M. (1967). Health Education: A conceptual approach to curriculum design, St. Paul, MN, 3M Company Educational Services.

Thompson, J.F. (1978). Using Roleplaying in the Classroom. Bloomington, IN, Phi Delta Kappa Educational Foundation.

Tonks, D. and Armitage, S. (1997). A framework for understanding learning from management simulations. Journal of Computer Assisted Learning, 13, 48-58.

Trigwell, K. and Prosser, M. (1996). Changing approaches to teaching: A relational perspective. Studies in Higher Education, 21, 275-284.

Turner, D. (1992). Roleplays: A sourcebook of activities for trainers, London, Kogan Page.

Van Ments, M., (1989). The effective use of role play: A handbook for teachers and trainers. Rev. ed., London, Kogan Page.

Vincent, A. and Shepherd, J. (1998). Teaching Middle East Politics by Interactive Computer Simulation. Journal for Instructional Multimedia in Education.

Westerhoff, J.H. (1976). Will our children have faith? Harper Collins, New York.

Mark Freeman and John Capper

Faculty of Business, University of Technology, Sydney

PO Box 222, Lindfield NSW 2070 Australia

Ph: +61295145425 +61295145360

Fax: + 61295145515

John.Capper@uts.edu.au 